\title{
Salvinal, a Novel Microtubule Inhibitor Isolated from Salvia miltiorrhizae Bunge (Danshen), with Antimitotic Activity in Multidrug-Sensitive and -Resistant Human Tumor Cells
}

\author{
Jang-Yang Chang, Chi-Yen Chang, Ching-Chuan Kuo, Li-Tzong Chen, Yung-Shung Wein, \\ and Yueh-Hsiung Kuo
}

Division of Cancer Research, National Health Research Institutes, Taipei 100, Taiwan (J.-Y.C., C.-Y.C., C.-C.K., L.-T.C.); and Department of Chemistry, National Taiwan University, Taipei, Taiwan (Y.-S.W., Y.-H.K.)

Received August 29, 2003; accepted October 10, 2003

This article is available online at http://molpharm.aspetjournals.org

\begin{abstract}
Aqueous extracts of Salvia miltiorrhizae Bunge have been extensively used in the treatment of cardiovascular disorders and cancer in Asia. Recently, a compound, 5-(3-hydroxypropyl)-7methoxy-2-(3'-methoxy-4'-hydroxyphenyl)-3-benzo[b]furancarbaldehyde (salvinal), isolated from this plant showed inhibitory activity against tumor cell growth and induced apoptosis in human cancer cells. In the present study, we investigated the cytotoxic effect and mechanisms of action of salvinal in human cancer cell lines. Salvinal caused inhibition of cell growth $\left(\mathrm{IC}_{50}\right.$ range, $4-17 \mu \mathrm{M}$ ) in a variety of human cancer cell lines. Flow cytometry analysis showed that salvinal treatment resulted in a concentration-dependent accumulation of cells in the $G_{2} / M$ phase. We observed, using Hoechst 33258 dye staining, that salvinal blocked the cell cycle in mitosis. In vitro and in vivo examinations showed that salvinal inhibited tubulin polymerization in a concentration-dependent manner. Immunocytochemical studies demonstrated that salvinal treatment caused the changes of cellular microtubule network, similar to the effect of
\end{abstract}

colchicine. In addition, salvinal treatment resulted in upregulation of cyclin B1 levels, activation of Cdc2 kinase, and Cdc25c phosphorylation. Furthermore, elevation of levels of MPM-2 phosphoepitopes in salvinal-treated cells in a concentration-dependent manner was also observed. Similar to the effect of other antitubulin agent, hyperphosphorylation of $\mathrm{Bcl}-2$, induction of DNA fragmentation and activation of caspase-3 activity occurred in salvinal-treated cells. In particular, salvinal exhibited similar inhibitory activity against parental KB, $\mathrm{P}$ glycoprotein-overexpressing KB vin10 and KB taxol-50 cells, and multidrug resistance-associated protein (MRP)-expressing etoposide-resistant KB 7D cells. Taken together, our data demonstrate that salvinal inhibits tubulin polymerization, arrests cell cycle at mitosis, and induces apoptosis. Notably, Salvinal is a poor substrate for transport by P-glycoprotein and MRP. Salvinal may be useful in the treatment of human cancers, particularly in patients with drug resistance.
Microtubules are the integral components of mitotic spindles, which are critical elements in a variety of fundamental functions, including chemotaxis, membrane and intracellular scaffolding, transport, secretory processes, regulatory of cellular motility, and cell division (Wittmann et al., 2001). Because microtubules play essential roles in the regulation of the mitotic apparatus, disrupting the microtubules can induce cell-cycle arrest in $\mathrm{M}$ phase and triggering the signals for programmed cell death. Many structurally diverse compounds have been reported to attack microtubules through their major structural component, tubulin (Paull et al., 1992), and cause mitotic arrest. Microtubule inhibitors interfere with the tubulin dynamics of tubulin polymerization and depolymerization, which results in the inhibition of cell division. The well-characterized clinically used antimitotic drugs, namely taxanes and Vinca alkaloids, have been used to treat various kinds of human cancers. Despite that the consequences of disrupting tubulin and microtubule dynamics with these drugs are the same (Blagosklonny et al., 1997), different microtubule inhibitors exert their effect on different dynamic directions of tubulin polymerization and exhibit different spectra of antitumor activity. The taxanes, including paclitaxel and docetaxel, stabilize microtubules and induce a net polymerization of microtubules (Schiff and Horwitz, 1980; Jordan et al., 1998). They are effective in the treatment of breast, lung, ovarian, bladder, and head and neck cancers

ABBREVIATIONS: P-gp, P-glycoprotein; DMSO, dimethyl sulfoxide; MAP, microtubule-associated protein; MRP, multidrug resistance-associated protein; PBS, phosphate-buffered saline; PIPES, piperazine-N, $N^{\prime}$-bis[2-ethanesulfonic acid]; salvinal, 5-(3-hydroxypropyl)-7-methoxy-2- (3'methoxy-4'-hydroxyphenyl)-3-benzo[b]furancarbaldehyde; PAGE, polyacrylamide gel electrophoresis; taxol, paclitaxel; VP-16, etoposide; AcDEVD-AMC, N-acetyl-Asp-Glu-Val-Asp-amino-4-methylcoumarin. 
(Rowinsky et al., 1990). The Vinca alkaloids, typified by vincristine, vinblastine, and vinorelbine, prevent the normal polymerization of microtubules (Jordan et al., 1998). They are important in the treatment of leukemia, lymphoma, small cell lung cancer, and other malignancies (Rowinsky and Donehower, 1991). Although the taxanes and the Vinca alkaloids are effective in the treatment of different kinds of human cancers, their potential is limited by the development of drug resistance. Resistance can be intrinsic or acquired, but in either case, tumors become refractory to a variety of structurally diverse anticancer drugs (Ramachandran and Melnick, 1999). The best characterized mechanism of drug resistance to microtubule inhibitors is mediated by the overexpression of the 170-kDa P-glycoprotein (P-gp) drug efflux pump that is encoded by the multidrug resistance- 1 gene and results in decreased drug accumulation (Germann, 1996; Ranganathan et al., 1996; Dumontet and Sikic, 1999). In addition, structural and functional alterations in the $\alpha$ - and $\beta$-tubulins, resulting from either genetic mutations or posttranslational modifications, have also been identified in tumor cells with acquired resistance to taxanes and Vinca alkaloids (Ranganathan et al., 1996; Kavallaris et al., 1997, 2001). Discovering new natural and synthetic compounds with effect in the treatment of drug-resistant tumors is therefore still attractive.

Salvia miltiorrhizae Bunge, commonly known as Danshen, has long been used as a traditional Chinese medicine for angina pectoris and acute myocardial infarction. Its nonplolar extracts contain tanshinones, which can inhibit platelet aggregation and protect myocardium against ischemia-induced derangement (Yagi et al., 1989; Lin et al., 2001). Aside from its cardiovascular protective effect, aqueous extracts of this plant have been used in the treatment of cancers for decades. It was reported that crude extract of $S$. miltiorrhizae markedly prolonged the survival period of Ehrlich ascites carcinoma-bearing mice, and tanshinone II-A sodium sulfonate, a compound isolated from this plant, could potentiate the cytotoxic action of hydroxycamptothecin against Ehrlich ascites carcinoma (Chang and But, 1986). In addition, several tanshinone analogs isolated from chloroform extract of S. miltiorrhizae exhibits cytotoxic activities against four types of cell lines derived from human carcinomas (Wu et al., 1991). Whether other compounds isolated from this plant exerting cytotoxic activities against human cancer cells remains unknown. A compound, 5-(3-hydroxypropyl)-7methoxy-2-(3'-methoxy-4' -hydroxyphenyl)-3-benzo[b]furancarbaldehyde (salvinal), was isolated from this herb, which has proven to be a potent adenosine antagonist (Yang et al., 1992; Scammells et al., 1998). Since the initial reports, which focused on the isolation, total synthesis, and A1 adenosine receptor affinity, the cytotoxic effect of this compound toward human cancer cells remained unexplored. Recently, we found that this compound possesses inhibitory activity against tumor cell growth and induces apoptosis in a variety of human solid tumor cell lines. In this study, we describe the detailed molecular mechanism of action of this compound. We found that the cytotoxic effect of salvinal is through the inhibition of tubulin polymerization. In particular, salvinal is also found to be active in cellular overexpression of P-gp and MRP.

\section{Materials and Methods}

Synthesis of Salvinal. Salvinal (Fig. 1) was synthesized at the Department of Chemistry, National Taiwan University (Taipei, Taiwan) with use of the method described by Kuo and Wu (1996). In brief, methyl ferulate was oxidized in acetone solution with aqueous ferric chloride to yield dihydrobenzofuran. Dihydrobenzofuran was then acetylated with acetic anhydride in pyridine. The acetylated dihydrobenzofuran was oxidized by dichlorodicyanobenzoquinone in dry benzene to afford a benzofuran. Benzofuran was hydrogenated with $10 \%$ palladium on carbon and $p$-toluenesulfonic acid in methanol solution and then simultaneously underwent deacetylation. The product was reprotected with a benzyl group, treated with diisobutyl aluminum hydride in dry tetrahydrofuran, selective-oxidized with manganese dioxide in ethyl acetate, and then finally deprotected with titanium tetrachloride in dichloromethane to obtain the target molecule as a yellowish solid. The desired product was confirmed by ${ }^{1} \mathrm{H}$ NMR and electron ionization/mass spectrometry and gave spectral data identical with literature values (Yang et al., 1991, 1992; Kuo and $\mathrm{Wu}, 1996)$. Melting point of the product was 78 to $80^{\circ} \mathrm{C}$ (literature m.p., $\left.77-77.5^{\circ} \mathrm{C}\right),{ }^{1} \mathrm{H} \mathrm{NMR}\left(300 \mathrm{MHz} \mathrm{CDCl}_{3}\right) \delta 1.94(\mathrm{~m}, 2$ H, H-2"), 2.81 (t, $\left.2 \mathrm{H}, J=7.3 \mathrm{~Hz}, \mathrm{H}-1^{\prime \prime}\right), 3.70$ (t, $\left.2 \mathrm{H}, J=6.5 \mathrm{~Hz}, \mathrm{H}-3^{\prime \prime}\right)$, $3.98(\mathrm{~s}, 3 \mathrm{H}), 4.00(\mathrm{~s}, 3 \mathrm{H}), 6.00(\mathrm{br} \mathrm{s}, 1 \mathrm{H}), 6.73(\mathrm{~d}, 1 \mathrm{H}, J=1.4 \mathrm{~Hz}$, H-6), $7.05\left(\mathrm{~d}, 1 \mathrm{H}, J=8.0 \mathrm{~Hz}, \mathrm{H}-5^{\prime}\right), 7.36(\mathrm{~d}, 1 \mathrm{H}, J=1.4 \mathrm{~Hz}, \mathrm{H}-4), 7.38$ (d, $\left.1 \mathrm{H}, J=8.0 \mathrm{~Hz}, \mathrm{H}-6^{\prime}\right), 7.64$ (s, 1H, H-2'), 10.26 (s, $1 \mathrm{H}, \mathrm{CHO}$ ). Electron ionization/mass spectrometry $\mathrm{m} / z(\%)$ : $(70 \mathrm{eV}) 356\left(\mathrm{M}^{+}\right.$, 95), 355 (14), 326 (30), 312 (100), 283 (31) 268 (28), 253 (23), 241 (27), 197 (22), 181 (31), and 165 (37).

Drugs, Enzymes, and Chemicals. Etoposide (VP-16), vincristine, paclitaxel (Taxol), and colchicine were purchased from Sigma Chemical Co. (St. Louis, MO). Polyclonal antibody to Cdc25c, monoclonal antibodies to Bcl-2, Cdc2, cyclin B1, and horseradish peroxidase-conjugated secondary antibody were purchased from Santa Cruz Biotechnology, Inc. (Santa Cruz, CA). Phosphospecific monoclonal antibody for MPM-2 was purchased from Upstate Biotechnology (Lake Placid, NY). Fluorescent isothiocyanate-conjugated secondary antibody was purchased from Ancell Corporation (Bayport, MN). Cell-culture reagents were obtained from Invitrogen (Carlsbad, CA). Microtubule-associated protein-rich (MAP-rich) tubulin was purchased from Cytoskeleton, Inc. (Denver, CO). $\left[{ }^{3} \mathrm{H}\right]$ Colchicine (specific activity, $60-87 \mathrm{Ci} / \mathrm{mmol}$ ) was purchased from PerkinElmer Life and Analytical Sciences (Boston, MA). All chemicals were standard analytical grade or higher.

Cell Lines. Human oral epidermoid carcinoma KB cells, nasopharyngeal carcinoma HONE-1 cells, colorectal carcinoma HT29 cells, nonsmall cell lung cancer $\mathrm{H} 460$ cells, and glioblastoma multiforme DBTRG cells were maintained in RPMI 1640 medium supplied with $5 \%$ fetal bovine serum. Human breast carcinoma MCF-7 cells, gastric carcinoma TSGH, and hepatocellular carcinoma HepG2 cells were maintained in minimal essential medium supplied with $5 \%$ fetal bovine serum. The vincristine-resistant cell line, KB vin10, and

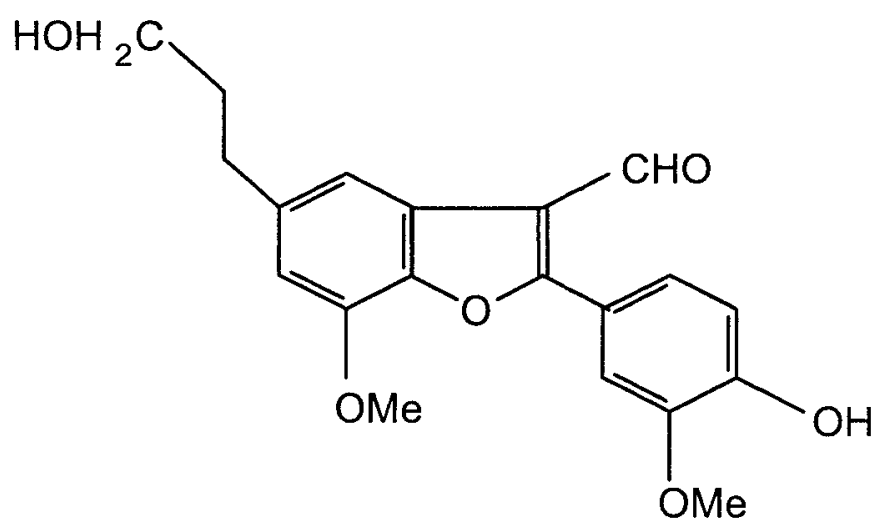

Fig. 1. Chemical structure of salvinal. 
the VP-16-resistant cells line, KB 7D, and the paclitaxel-resistant cell line, $\mathrm{KB}$ taxol-50, were maintained in growth medium supplemented with $10 \mathrm{nM}$ vincristine, $7 \mu \mathrm{M}$ VP-16, and $50 \mathrm{nM}$ paclitaxel, respectively. $\mathrm{KB}$ vin 10 and $\mathrm{KB}$ taxol-50 cells overexpressed P-gp (J.-Y. Chang, unpublished data). KB 7D displayed a decrease in cellular topoisomerase II content, and overexpression of MRP (Ferguson et al., 1988).

Growth Inhibition Assay. Cells in the logarithmic phase were cultured at a density of 5000 cells $/ \mathrm{ml} /$ well in a 24 -well plate. The resistant cells were cultured in drug-free medium for 3 days before use. The cells were exposed to various concentrations of the test drugs for $72 \mathrm{~h}$. The methylene blue dye assay was used to evaluate the effect of the test drugs on cell growth, as described previously (Finlay et al., 1984), and to determine the concentration of drug that inhibited $50 \%$ of cell growth $\left(\mathrm{IC}_{50}\right)$.

Cell-Cycle Analysis. Cells were incubated with various concentrations of salvinal for $24 \mathrm{~h}$. After treatment, cells were washed with phosphate-buffered saline (PBS) and fixed in ice-cold 70\% ethanol. The fixed cells were incubated with $5 \mu \mathrm{g} / \mathrm{ml}$ RNase I and $1 \mu \mathrm{g} / \mathrm{ml}$ propidium iodide, and then cellular DNA content was determined by a fluorescence-activated cell sorting IV flow cytometer (BD Biosciences, San Jose, CA). For quantitative assay of mitotic cells, after staining with Hoechst 33258 dye (Heald et al., 1993), at least 200 cells and those with chromosome condensation were counted.

In Vitro Microtubule Assembly Assay. Microtubule polymerization was conducted in a 96-well microtiter plate with MAP-rich tubulin and various concentrations of salvinal in a buffer containing $100 \mathrm{mM}$ PIPES, $\mathrm{pH} 6.9,2 \mathrm{mM} \mathrm{MgCl}_{2}, 1 \mathrm{mM} \mathrm{GTP}$, and $4 \%(\mathrm{v} / \mathrm{v})$ dimethyl sulfoxide (DMSO). The increase in absorbance was measured at $350 \mathrm{~nm}$ in a PowerWave X Microplate Reader (Bio-Tek Instruments, Winooski, VT) at $37^{\circ} \mathrm{C}$ and recorded every $30 \mathrm{~s}$ for 30 min. The area under the curve was used to determine the concentration that inhibited tubulin polymerization by $50 \%\left(\mathrm{IC}_{50}\right)$. The area under the curve of the untreated control was set to $100 \%$ polymerization, and the $\mathrm{IC}_{50}$ was calculated using nonlinear regression.

In Vivo Microtubule Assembly Assay. Separation of polymerized tubulin from tubulin dimmers and analysis of the effect of salvinal on tubulin polymerization in intact cells were performed as described by Blagosklommy et al. (1995). In brief, HONE-1 cells at a density of $1 \times 10^{6} /$ dish were treated with indicated concentrations of test agents for $24 \mathrm{~h}$. Then, cells were washed with PBS three times before adding lysis buffer containing $20 \mathrm{mM}$ Tris-HCl, $\mathrm{pH} 8.6,1 \mathrm{mM}$ $\mathrm{MgCl}_{2}, 2 \mathrm{mM}$ EGTA, $1 \mathrm{mM}$ phenylmethylsulfonyl fluoride, $20 \mu \mathrm{g} / \mathrm{ml}$ aprotinin and leupeptin, $1 \mathrm{mM}$ orthovanadate, and $0.5 \%$ Nonidet $\mathrm{P}-40$. Supernatants were collected after centrifugation at $10,000 \mathrm{rpm}$ for $10 \mathrm{~min}$ at $4^{\circ} \mathrm{C}$. The pellets were dissolved in a SDS-polyacrylamide gel electrophoresis (PAGE) sampling buffer and subjected to electrophoresis on a $10 \%$ SDS-PAGE gel. After electrophoresis, the proteins were transferred to a nitrocellulose membrane, and the membrane was then incubated with $\alpha$-tubulin monoclonal antibody (Sigma). Detection of immunoreactive signal was accomplished with Western Blot Chemiluminescent Reagent Plus (PerkinElmer Life and Analytical Sciences).

Immunocytochemistry. HONE-1 cells plated on coverslips were treated with different concentrations of salvinal for $6 \mathrm{~h}$. Colchicine and paclitaxel were included as control. After treatment, cells were fixed in the fixed solution [methanol/acetone; $1: 1(\mathrm{v} / \mathrm{v})$ ] for $1 \mathrm{~h}$ at $-20^{\circ} \mathrm{C}$ and washed with PBS. Then the cells were blocked with $3 \%$ bovine serum albumin in PBS for $1 \mathrm{~h}$ and further incubated with $3 \%$ bovine serum albumin in PBS containing anti- $\alpha$-tubulin monoclonal antibody for $2 \mathrm{~h}$ at room temperature. After being washed with PBS, cells were reincubated with fluorescent isothiocyanate-conjugated secondary antibody in the dark room for $1 \mathrm{~h}$. Cellular microtubules were observed with an Olympus BX50 fluorescence microscope (Opelco, Dulles, VA).

Colchicine and Tubulin Competition-Binding Assay. Tubulin was incubated with $\left[{ }^{3} \mathrm{H}\right]$ colchicine in the presence of different concentrations of either unlabeled colchicine or salvinal in a buffer containing 0.05 M PIPES, pH 6.9, $1 \mathrm{mM} \mathrm{MgCl}_{2}$, and $1 \mathrm{mM}$ GTP. The reaction mixtures were incubated at $37^{\circ} \mathrm{C}$ for $1 \mathrm{~h}$. The samples were loaded onto a Sephadex G-50 column (Amersham Biosciences Inc., Piscataway, NJ) previously equilibrated with the buffer solution. The columns were placed into 1.5 -ml tubes and spun at $750 \mathrm{~g}$ for 2 $\mathrm{min}$ at room temperature, and radioactivity in the flow-through was analyzed by a scintillation counter.

Apoptosis Studies. Cells were washed once with ice-cold PBS, dissolved in lysis buffer (10 mM Tris, $10 \mathrm{mM}$ EDTA, and 0.5\% Triton $\mathrm{X}-100$ ), and then incubated for $10 \mathrm{~min}$ at $4^{\circ} \mathrm{C}$. Samples were spun down at $16,000 \mathrm{rpm}$ for $20 \mathrm{~min}$. Fragmented DNAs were isolated with the use of Wizard DNA Purification Kits (Promega, Madison, WI) and analyzed by electrophoresis on a $1.5 \%$ agarose gel. In addition, caspase- 3 activation by HONE- 1 cells after treating with various concentrations of salvinal for $24 \mathrm{~h}$ in triplicate at $37^{\circ} \mathrm{C}$ in 96 microtiter plates was measured by the cleavage of the fluorometric substrate Ac-DEVD-AMC according to the manufacturer's procedure (Promega).

Western Blot Analysis. Cells were initially seeded at $1 \times 10^{6}$ cells in $100-\mathrm{mm}^{2}$ dishes. After treatment with various concentrations of salvinal for $24 \mathrm{~h}$, adherent and floating cells were collected and lysed in ice-cold lysis buffer (50 mM Tris, $\mathrm{pH} 7.4$, 0.8 M NaCl, $5 \mathrm{mM}$ $\mathrm{MgCl}_{2}, 0.5 \%$ Nonidet P-40, $1 \mathrm{mM}$ phenylmethylsulfonyl fluoride, 1 $\mu \mathrm{g} / \mathrm{ml}$ pepstatin, and $50 \mu \mathrm{g} / \mathrm{ml}$ leupeptin) and cleared by microcentrifugation. Protein concentrations of lysates were determined using the BCA Protein Assay Reagent (Pierce Chemical, Rockford, IL), with bovine serum albumin as standard. Total cell lysates $(50 \mu \mathrm{g})$ were separated by SDS-PAGE and electrophoretically transferred onto nitrocellulose membranes. Filters were blocked with $5 \%$ skim milk/PBS-Tween 20 overnight at $4^{\circ} \mathrm{C}$ and probed with appropriate dilutions (as recommended by the manufacturers) of primary antibodies for $1 \mathrm{~h}$ at room temperature. Membranes were then washed three times in PBS containing 0.1\% Tween 20 and subsequently incubated with appropriate horseradish peroxidase-conjugated secondary antibody for $1 \mathrm{~h}$ at room temperature. After washing, immunoreactive proteins were visualized using Western Blot Chemiluminescent Reagent Plus (PerkinElmer Life and Analytical Sciences).

\section{Results}

Effect of Salvinal on Cell Proliferation and Apoptosis in Human Solid Tumor Cells. The antiproliferative effect of salvinal was determined in various human cancer cell lines including oral, nasopharyngeal, breast, lung, colon, stomach, and brain tumor cells. Table 1 lists the $\mathrm{IC}_{50}$ values of salvinal tested in a variety of cancer cell lines. The $\mathrm{IC}_{50}$ values of salvinal were in the range of 4 to $17 \mu \mathrm{M}$, depending on the cell lines. HONE-1 cells exhibited the highest susceptibility to salvinal with an $\mathrm{IC}_{50}$ of $\sim 4 \mu \mathrm{M}$. HT 29 cells displayed the lowest susceptibility to salvinal with an $\mathrm{IC}_{50}$ of $\sim 17 \mu \mathrm{M}$. We then examined whether salvinal could induce apoptosis. HONE-1 cells were treated with different concentrations of salvinal for $24 \mathrm{~h}$. Salvinal-induced apoptosis was determined both by DNA fragmentation and caspase-3 activation assay. Figure 2A shows salvinal-induced apoptosis in a concentration-dependent manner in HONE-1 cells. Furthermore, salvinal also induces apoptosis in a time-dependent manner in HONE-1 cells (data not shown). The formation of the DNA ladder was evident at a concentration of 8 $\mu \mathrm{M}$. In addition, we also observed an increase in the ability of cell lysates to clear the caspase-3 substrate, Ac-DEVD-AMC, in a concentration-dependent manner (Fig. 2C).

Effect of Salvinal on Cell Cycle. The effect of different concentrations of salvinal on cell-cycle progression of HONE-1 cells was studied after $24 \mathrm{~h}$ of drug exposure. Salvi- 
TABLE 1

Growth inhibition of salvinal against human tumor cell lines Values are averages \pm S.D. of at least three independent experiments.

\begin{tabular}{llr}
\hline \multicolumn{1}{c}{ Cell Lines } & \multicolumn{1}{c}{ Origin } & \multicolumn{1}{c}{$\mathrm{IC}_{50}$} \\
\hline & & $\mu M$ \\
KB & Oral carcinoma & $5 \pm 0.5$ \\
HONE-1 & Nasopharyngeal carcinoma & $4.1 \pm 0.2$ \\
TSGH & Stomach carcinoma & $5.6 \pm 0.6$ \\
MCF-7 & Breast carcinoma & $9.2 \pm 1.2$ \\
HepG2 & Hepatocellular carcinoma & $7.4 \pm 0.8$ \\
HT29 & Colon carcinoma & $17 \pm 1.2$ \\
H460 & Non-small-cell lung cancer & $5.3 \pm 0.4$ \\
DBTRG & Glioblastoma multiforme & $7.1 \pm 0.2$ \\
\hline
\end{tabular}

A

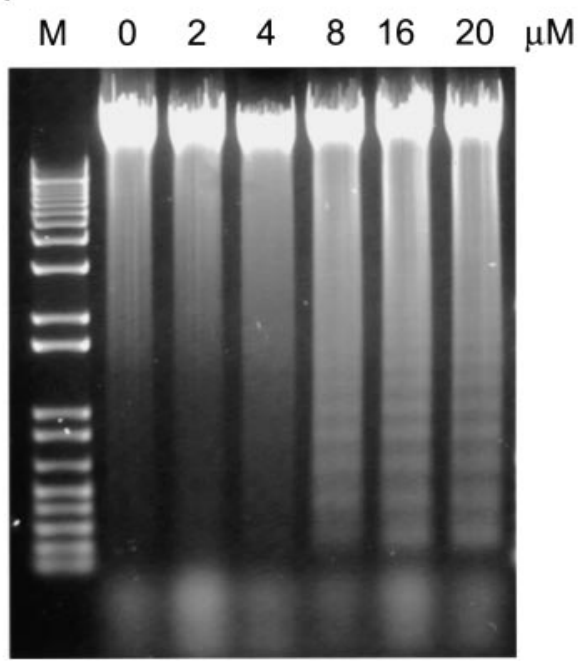

B

$\begin{array}{lllllll}0 & 2 & 4 & 8 & 16 & 20 & \mu \mathrm{M}\end{array}$

$\mathrm{Bcl}-2$

C

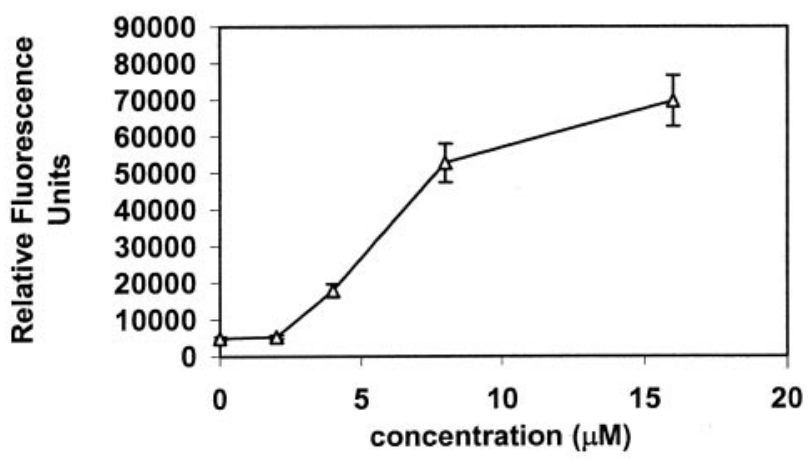

Fig. 2. Salvinal induces apoptosis and Bcl-2 phosphorylation in HONE-1 cells. A, salvinal induces DNA laddering fragmentation. HONE-1 cells were treated with the indicated concentrations of salvinal for $24 \mathrm{~h}$. After treatment, cells were lysed with lysis buffer, and DNA was extracted as described under Materials and Methods. DNA was dissolved in TE buffer and subjected to electrophoresis in a $1 \%$ agarose gel. DNA laddering was visualized by UV light illumination. B, cells were treated with indicated concentrations of salvinal for $24 \mathrm{~h}$. Cellular extracts were prepared and analyzed by SDS-PAGE and Western blotting as described under Materials and Methods. C, concentration-dependent increase in caspase-3 activation (Ac-DEVD-AMC) in HONE-1 cells after treatment for $24 \mathrm{~h}$ Each point represents the mean \pm S.D. of three independent experiments. nal treatment resulted in a concentration-dependent accumulation of HONE- 1 cells in the $\mathrm{G}_{2} / \mathrm{M}$ phase with concomitant losses from $G_{0} / G_{1}$ phase (Fig. $3 A$ ). No change of $S$ phase was observed. The increment of sub- $\mathrm{G}_{1}$ cells reached a plateau at the concentration of $8 \mu \mathrm{M}$ salvinal. Similar results

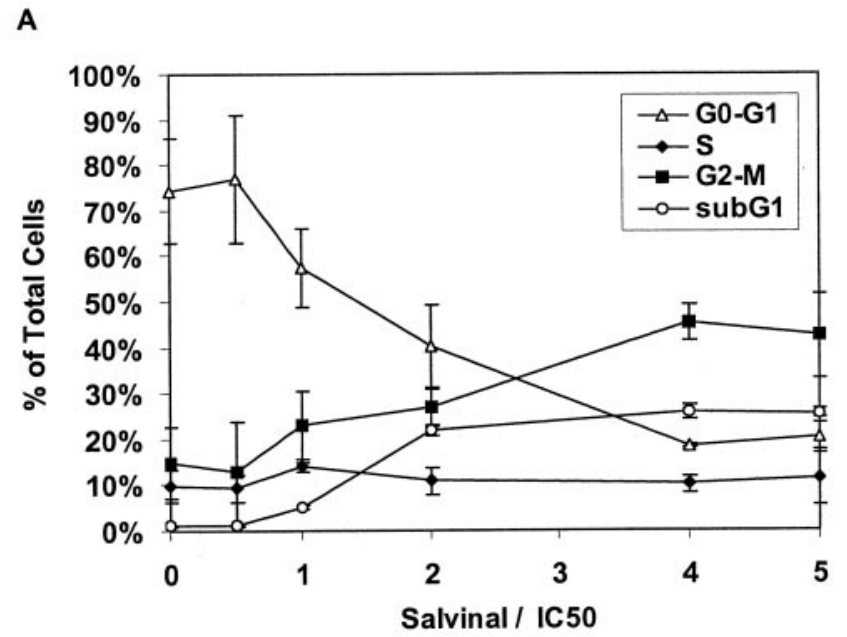

B
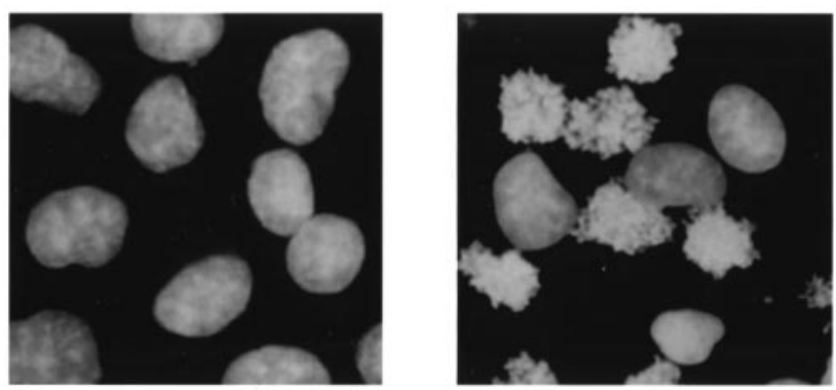

C

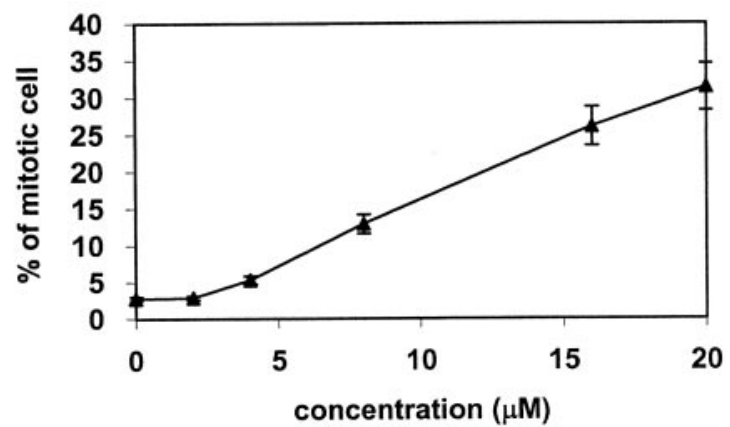

Fig. 3. A, effect of salvinal on cell-cycle progression of HONE-1 cells. The cell-cycle analysis was done as described under Materials and Methods. Cells were treated with various concentrations of salvinal expressed as multiples of $\mathrm{IC}_{50}$ values (salvinal/ $\mathrm{IC}_{50}$ ) for $24 \mathrm{~h}$. The $\mathrm{IC}_{50}$ was derived from the growth inhibition assay. Each point represents the mean + S.D. of three independent experiments. B, morphological examination of salvinal-induced M-phase arrest. HONE-1 cells were treated with different concentrations of salvinal for $24 \mathrm{~h}$. After treatment, cells were harvested and stained with Hoechst 33258. Control cells were in interphase with intact nuclei (left), whereas in salvinal-treated cells, typical metaphase arrest cells presented with condensed chromosome (right) C, quantitative assessment of mitotic arrest by salvinal. HONE-1 cells were treated with different concentrations of salvinal for $24 \mathrm{~h}$. Cells were stained with Hoechst 33258 dye, and the mitotic cells were counted for at least 200 cells. Cells with hypercondensed aggregates of chromatin were defined as mitotic cells. Each point represents the mean \pm S.D. from three independent experiments. 
were obtained with other cell lines (e.g., KB and HepG2 cells; data not shown). For quantitative analysis of mitotic arrest, cells were stained with Hoechst 33258, and the percentage of mitotic cells was calculated after counting at least 200 cells.

A

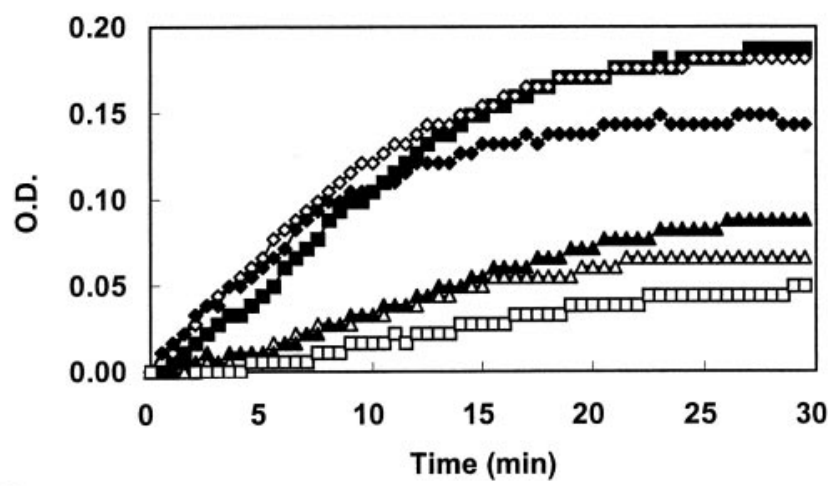

B

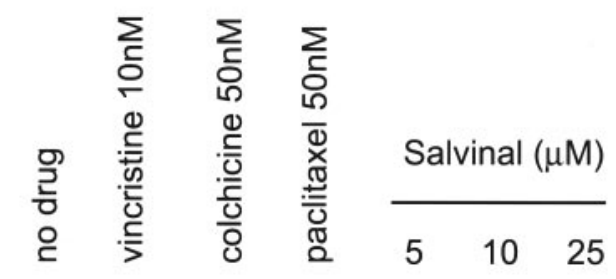

Insoluble

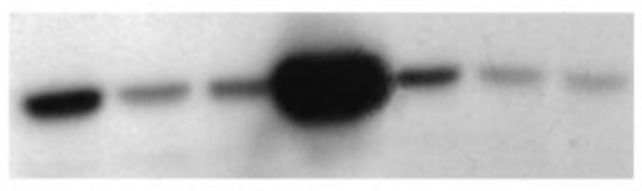

Soluble

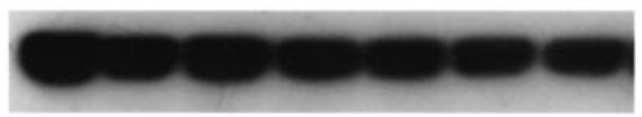

C

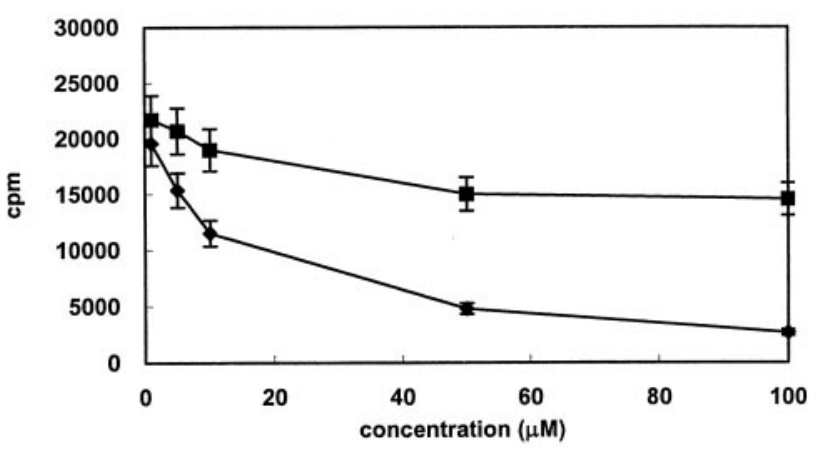

Fig. 4. A, effect of salvinal on microtubule assembly in vitro. MAP-rich tubulin in a reaction buffer was incubated at $37^{\circ} \mathrm{C}$ in the presence of $4 \%$ $(\mathrm{v} / \mathrm{v})$ DMSO $(\mathbf{\square})$, and $1 \mu \mathrm{M}(\diamond), 10 \mu \mathrm{M}(\diamond), 25 \mu \mathrm{M}(\mathbf{\Delta})$, and $50 \mu \mathrm{M}(\square)$ salvinal. Colchicine ( $5 \mu \mathrm{M}, \mathbf{\Delta}$ ) was used as a positive control. This result is the representative of three independent experiments. B, effect of salvinal on tubulin polymerization in vivo. Cells were treated with vincristine $(10 \mathrm{nM})$, colchicine $(50 \mathrm{nM})$, paclitaxel $(50 \mathrm{nM})$, and 5,10 , and $25 \mu \mathrm{M}$ salvinal for $24 \mathrm{~h}$ at $37^{\circ} \mathrm{C}$. The in vivo tubulin polymerization assay was done as described under Materials and Methods. C, binding of salvinal to the colchicine site of tubulin, as determined by spin-column assay, as described under Materials and Methods. The concentrations for colchicine $(\checkmark)$ and salvinal (ם) were $1,5,10,50$, and $100 \mu \mathrm{M}$. Data represent means \pm S.D. from three independent experiments performed in duplicate.
Microscopic examination showed that HONE-1 cells treated with salvinal for $24 \mathrm{~h}$ led to cell-cycle arrest at metaphase with chromosome condensation compared with untreated cells with intact nuclei (Fig. 3B). We further calculated the values of $\mathrm{M}$-phase cells treated with different concentrations of salvinal for $24 \mathrm{~h}$, as shown in Fig. 3C; approximately $3 \%$ of cells were at $\mathrm{M}$ phase at time 0 , and M-phase cells increased in a concentration-dependent manner and reached up to $\sim 30 \%$ at the concentration of $20 \mu \mathrm{M}$.

Effect of Salvinal on Tubulin Polymerization. Because salvinal treatment caused cell accumulation in the $\mathrm{G}_{2} / \mathrm{M}$ phase, we then investigated whether salvinal could inhibit tubulin polymerization. To test this hypothesis, the effect of salvinal on microtubule polymerization was first examined in vitro. Figure $4 \mathrm{~A}$ shows the result of microtubule assembly in vitro using MAP-rich tubulin. In control samples, absorbance at $350 \mathrm{~nm}\left(A_{350}\right)$ increased with time. The increase of $A_{350}$ reaches a plateau in $20 \mathrm{~min}$. In the presence of $5 \mu \mathrm{M}$ colchicine, tubulin polymerization was inhibited more than $50 \%$ compared with that of the control sample. Furthermore, in the presence of salvinal, tubulin polymerization was inhibited in a concentration-dependent manner. The inhibitory concentration that reduced the polymerized tubulin by $50 \%$ is $17 \pm 3 \mu \mathrm{M}(n=3)$. In Fig. $4 \mathrm{~B}$, the effect of salvinal on microtubule assembly was compared with those of paclitaxel, vincristine, and colchicine during an in vivo

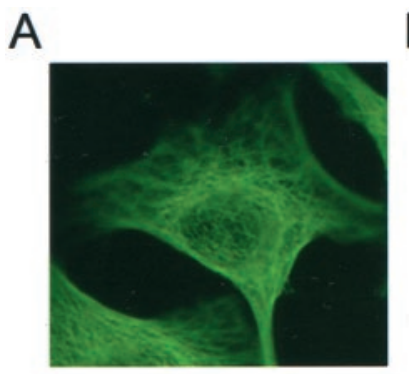

B

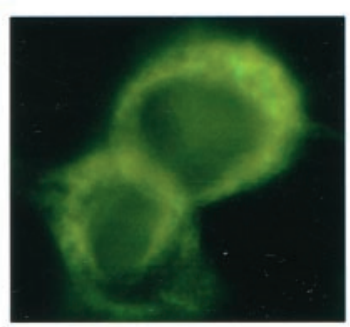

C

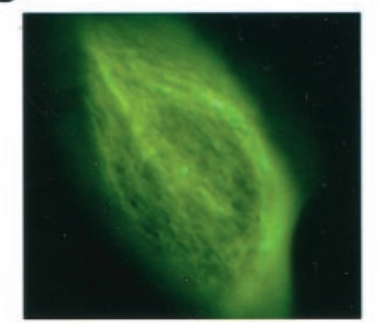

D

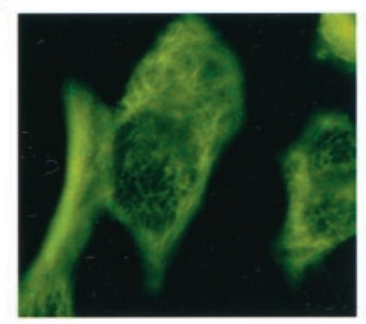

E

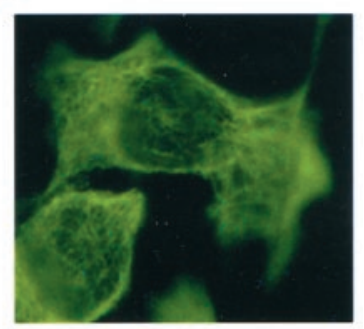

$\mathrm{F}$

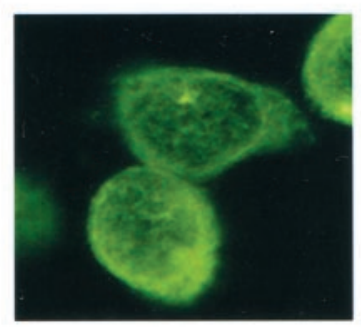

Fig. 5. Effect of salvinal on cellular microtubule organization. Cellular microtubules were visualized with indirect immunofluorescence techniques using a monoclonal $\alpha$-tubulin antibody after an 6-h incubation vehicle control, DMSO (A), 0.5 $\mu \mathrm{M}$ colchicine (B), $0.5 \mu \mathrm{M}$ paclitaxel (C), and $12.5(\mathrm{D}), 25(\mathrm{E})$, and $50 \mu \mathrm{M}(\mathrm{F})$ salvinal. The images were representative of two independent experiments. 
assay. In the presence of $50 \mathrm{nM}$ colchicine and $10 \mathrm{nM}$ vincristine, the inhibition of microtubule assembly was observed, whereas $50 \mathrm{nM}$ paclitaxel promoted tubulin polymerization. Similar to the effect of colchicine and vincristine, salvinal prevented tubulin polymerization in a concentration-dependent manner. We further examined the effect of salvinal on cellular microtubule network using immunofluorescence techniques. The microtubule network in control cells exhibited normal organization and arrangement (Fig. 5A). Treatment with colchicine caused cellular microtubule depolymerization with short microtubules in the cytoplasm (Fig. 5B). In contrast, paclitaxel treatment resulted in microtubule polymerization with an increasing in the density of cellular microtubules (Fig. 5C). Furthermore, salvinal treatment resulted in findings similar to those of colchicine-induced microtubule changes (Fig. 5, D-F). We further determined the nature of salvinal interactions with tubulin by binding colchicine-binding domains on tubulin using spin column assay. As shown in Fig. 4C, tubulin incubation with $\left[{ }^{3} \mathrm{H}\right]$ colchicine in the presence of unlabeled colchicine reduced the amount of $\left[{ }^{3} \mathrm{H}\right]$ colchicine found in the flow-through in a concentration-dependent manner. At concentrations up to 50 $\mu \mathrm{M}$, salvinal reduced the amount of $\left[{ }^{3} \mathrm{H}\right]$ colchicine in the flow-through. No further reduction in radioactivity was observed at salvinal concentrations greater than $50 \mu \mathrm{M}$.

Effect of Salvinal on the $G_{2} / M$ Regulatory Protein and Bcl-2. To determine the relationship between salvinalinduced mitotic arrest, cyclin B1/Cdc2 activity, and Cdc25c and Bcl-2 phosphorylation, we initially examined the status of these $\mathrm{G}_{2} / \mathrm{M}$ regulatory proteins in HONE-1 cells. After $24 \mathrm{~h}$ of salvinal treatment, slower migration forms of phosphatase Cdc25c and the antiapoptotic protein Bcl-2 were present in

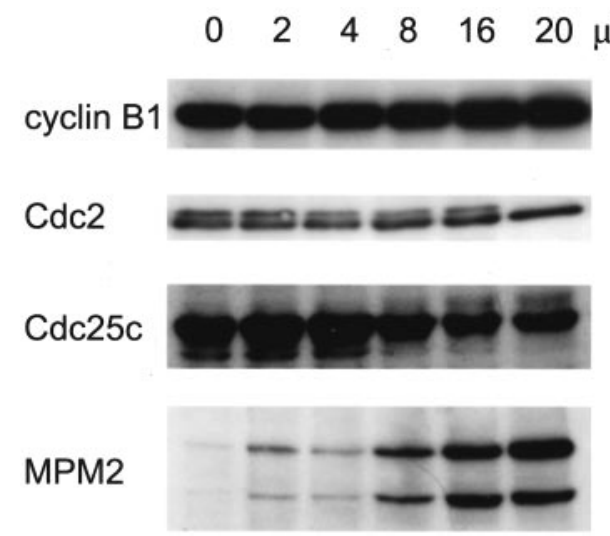

Fig. 6. Salvinal induces changes in the phosphorylation state of $G_{2} / M$ regulatory proteins. Cells were treated with indicated concentrations of salvinal for $24 \mathrm{~h}$, and then cell extracts were prepared for immunoblot analysis. Equal amounts of extract from each sample were electrophoresed on SDS-PAGE, transferred to blots, and probed with Cdc25c, Cdc2, cyclin B1, and MPM-2 antibodies. cells (Figs. 2B and 6), indicative of changes in the phosphorylation state of these proteins. Changes of Cdc25c and Bcl-2 hyperphosphorylation were evident after treatment of cells with 8 and $16 \mu \mathrm{M}$ of salvinal, respectively. As the dose of salvinal increased from 8 to $20 \mu \mathrm{M}$, there was an increase in phosphorylation of Cdc25c. In contrast, there was a shift to faster migration form of the cyclin-dependent kinase, Cdc2, consistent with the hypophopshorylated, active form of the protein. However, only slight up-regulation of the cyclin B1 level was observed. We further examined the status of phosphorylation polypeptides found only in mitotic cells using MPM-2 antibody (Scatena et al., 1998). After 24-h treatment with salvinal, significant elevation in the levels of MPM-2 phosphoepitopes in a concentration-dependent manner was observed.

Effect of Salvinal on Cell Proliferation in MultidrugResistant Cell Lines. Because the most thoroughly described drug-resistant mechanisms for microtubule inhibitors are overexpression of P-gp and MRP, we examined whether salvinal is cross-resistant with microtubule inhibitors in these drug-resistant cell lines. We treated parental $\mathrm{KB}$ cells, P-gp-overexpression $\mathrm{KB}$ vin10 and $\mathrm{KB}$ taxol-50 cells, and MRP-positive VP-16-resistant KB 7D cells with salvinal, vincristine, VP-16, paclitaxel, and colchicine for 72 h. As shown in Table 2, Salvinal displays no cross-resistance with vincristine, paclitaxel, VP-16, and colchicine in these drug-resistant cell lines. These data indicate that salvinal, despite acting as a microtubule inhibitor, is a poor substrate of P-gp and MRP.

\section{Discussion}

The aqueous extracts of $S$. miltiorrhizae Bunge have long been used as a traditional Chinese herb medicine in the treatment of cardiovascular diseases, chronic hepatitis, and cancer (Chang and But, 1986). Several active ingredients have been identified that are effective in protecting liver microsomes, hepatocytes, and erythrocytes against oxidative damage; inhibiting platelet aggregation; and reducing atherosclerosis, which results in protecting myocardium from ischemic damage (Yagi et al., 1989; Liu et al., 1992). The specific components responsible for the antitumor activity from $S$. miltiorrhizae were primarily focused on one group of diterpenoids with a furano-1,2- or a furano-1,4-naphthoquinone skeleton (tanshinones), but the mechanism of action of these compounds remained to be elucidated. In the present study, we demonstrate that salvinal, another compound isolated from $S$. miltiorrhizae, is effective in inhibiting the cell proliferation and inducing apoptosis of various human cancer cells. Notably, salvinal in vitro was effective against three KB-resistant cells despite their P-gp or MRP status. This feature was distinct from vincristine, colchicine, VP-16, and

TABLE 2

Growth inhibition of various compounds against different drug-resistant cell lines $\left(\mathrm{IC}_{50}\right)$

Values are averages \pm S.D. of at least three independent experiments.

\begin{tabular}{lrccc}
\hline \multicolumn{1}{c}{ Compound } & \multicolumn{1}{c}{ KB } & KB vin10 & KB 7D & taxol-50 \\
\hline Salvinal $(\mu \mathrm{M})$ & $5 \pm 0.5$ & $3.7 \pm 0.6$ & $3.3 \pm 1.0$ & $3.7 \pm 0.5$ \\
Vincristine $(\mathrm{nM})$ & $0.4 \pm 0.1$ & $57 \pm 5$ & $0.9 \pm 0.2$ & $2.5 \pm 0.1$ \\
VP-16 $(\mu \mathrm{M})$ & $1.1 \pm 0.2$ & $23 \pm 3$ & $54 \pm 3.5$ & $3.5 \pm 0.3$ \\
Paclitaxel $(\mathrm{nM})$ & $3.3 \pm 0.7$ & $12,500 \pm 43$ & $7.5 \pm 1$ & $273 \pm 15$ \\
Colchicine $(\mathrm{nM})$ & $9 \pm 0.6$ & $125 \pm 3.5$ & $54 \pm 2$ & $15 \pm 1$ \\
\hline
\end{tabular}


paclitaxel because these three KB-resistant cells were more resistant to these chemotherapeutics than were $\mathrm{KB}$ cells. These data indicated that salvinal is a poor substrate for transport by $\mathrm{P}$-gp or by MRP, suggesting that it might be useful for treating drug-refractory patients, particularly those with microtubule-interacting agent resistance.

Salvinal treatment resulted in a concentration-dependent accumulation of HONE-1 cells in $\mathrm{G}_{2} / \mathrm{M}$ phase and caused an M-phase arrest. We hypothesized that salvinal could directly affect tubulin. Using in vitro and in vivo tubulin polymerization assays (Fig. 4, A and B), we found that salvinal inhibited tubulin polymerization in a concentration-dependent manner. In addition, in contrast to paclitaxel-promoted tubulin polymerization, the pattern of salvinal-inhibited tubulin polymerization was similar to that of colchicine and vincristine. This was further confirmed by an immunocytochemical study showing that the effect of salvinal on cellular microtubule network was similar to that of colchicine (Fig. 5). Salvinal thus can be classified as a "microtubule-depolymerizing agent". Microtubule-depolymerizing agents can be classified into categories depending on their binding sites on $\beta$-tubulin. Colchicine, flavonols, podophyllotoxin, and combretastatins bind to the "colchicine" domain; Vinca alkaloids, rhizoxin dolastatin, and phomopsin A bind to the "Vinca" domain (Hamel, 1996). We determined the effect of salvinal on $\left[{ }^{3} \mathrm{H}\right]$ colchicine binding to $\beta$-tubulin by competition assay. Our results show that the binding of colchicine is reduced by the salvinal, which shows that salvinal can interact in some way with tubulin. The reduction could occur by a variety of mechanisms, some having nothing to do with the binding of salvinal in the vicinity of the colchicine.

Progression of cells from interphase to mitosis involves major alterations in cellular structures and activities. It is well established that $\mathrm{Cdc} 2 /$ cyclin B complexes are involved in regulation of the $\mathrm{G}_{2} / \mathrm{M}$ phase and the $\mathrm{M}$-phase transition. The activation of Cdc2 requires association with cyclin $\mathrm{B}$ and phosphorylation by a cyclin-dependent kinase-activating kinase (Russo et al., 1996; Draetta, 1997). The activation of Cdc2 is accomplished by the phosphatase Cdc25c (Kumagai and Dunphy, 1991; Strausfeld et al., 1991). During mitosis, Cdc2 and Cdc25c is present in a hypophosphorylated and hyperphosphorylated, respectively, active form (Hoffmann et al., 1993). In addition, studies have shown that many phosphorylated polypeptides, recognized by MPM-2 antibody, can only be detected in mitotic cells (Davis et al., 1983; Westendorf et al., 1994). Our results show that in addition to directly disrupting microtubules, treatment with salvinal results in the engagement of active Cdc2 kinase, and phosphorylation of Cdc25c, Bcl-2, and MPM-2 epitopes. These changes in protein phosphorylation are consistent with anti-tubulin agent-induced cell-cycle arrest in mitosis, as shown previously (Scatena et al., 1998).

The Bcl-2 family plays a central role in the control of apoptosis. Studies have shown that Bcl-2 can promote cell survival by inhibiting the process of programmed cell death or apoptosis (Korsmeyer, 1995). Overexpression of Bcl-2 has been shown to prevent chemotherapeutic agent-induced apoptosis associated with altered mitochondria membrane potential (Decaudin et al., 1997). Furthermore, treatment of cells with phosphatase inhibitor resulted in cell death, suggesting that phosphorylation of Bcl-2 inhibits its function (Haldar et al., 1995). In addition, a number of studies indi- cated that microtubule inhibitors, including paclitaxel and vinblastine, are able to induce apoptosis by stimulating Bcl-2 phosphorylation (Jiang et al., 1998; Tahir et al., 2001). In our study, we show that like other microtubule inhibitors, salvinal is able to induce Bcl-2 phosphorylation and apoptosis. Although many microtubule-interacting agents cause the appearance of two slower migrating bands, suggesting multiple phosphorylation states, this was not observed with salvinal, indicating the possibility of subtle differences in Bcl-2 phosphorylation among the microtubule-interacting agents.

In conclusion, we demonstrate for the first time that salvinal, a natural product isolated from $S$. miltiorrhizae Bunge, has antiproliferative activity against various human solid tumor cells. It seems to inhibit mitosis in cancer cells. In particular, salvinal displays no cross-resistance with known existing microtubule inhibitors, including Vinca alkaloids and taxanes, in cells overexpressing P-gp or MRP. Further exploration of salvinal as an antitumor compound is worthwhile.

\section{References}

Blagosklonny MV, Giannakakou P, el Deiry WS, Kingston DG, Higgs PI, Neckers L, and Fojo T (1997) Raf-1/Bcl-2 phosphorylation: a step from microtubule damage to cell death. Cancer Res 57:130-135.

Blagosklonny MV, Schulte TW, Nguyen P, Mimnaugh EG, Trepel J, and Neckers L (1995) Taxol induction of P21WAF1 and P53 requires C-Raf-1. Cancer Res 55: 4623-4626.

Chang HM and But PP (1986) Pharmacology and Applications of Chinese Material Medica, World Scientific Publication, Singapore.

Davis FM, Tsao TY, Fowler SK, and Rao PN (1983) Monoclonal antibodies to mitotic cells. Proc Natl Acad Sci USA 80:2926-2930.

Decaudin D, Geley S, Hirsch T, Castedo M, Marchetti P, Macho A, Kofler R, and Kroemer G (1997) Bcl-2 and Bcl-XL antagonize the mitochondrial dysfunction preceding nuclear apoptosis induced by chemotherapeutic agents. Cancer Res 57:62-67.

Draetta GF (1997) Cell cycle: will the real Cdk-activating kinase please stand up. Curr Biol 7:R50-R52.

Dumontet C and Sikic BI (1999) Mechanisms of action of and resistance to antitubulin agents: microtubule dynamics, drug transport and cell death. J Clin Oncol 17:1061-1070.

Ferguson PJ, Fisher MH, Stephenson J, Li DH, Zhou BS, and Cheng YC (1988) Combined modalities of resistance in etoposide-resistant human $\mathrm{KB}$ cell lines. Cancer Res 48:5956-5964.

Finlay GJ, Baguley BC, and Wilson WR (1984) A semiautomated microculture method for investigating growth inhibitory effects of cytotoxic compounds on exponentially growing carcinoma cells. Anal Biochem 139:272-277.

Germann UA (1996) P-Glycoprotein-a mediator of multidrug resistance in tumour cells. Eur J Cancer 32A:927-944.

Haldar S, Jena N, and Croce CM (1995) Inactivation of Bcl-2 by phosphorylation. Proc Natl Acad Sci USA 92:4507-4511.

Hamel E (1996) Antimitotic natural products and their interactions with tubulin. Med Res Rev 16:207-231.

Heald R, McLoughlin M, and Mckeon F (1993) Human Wee1 maintains mitotic timing by protecting the nucleus from cytoplasmically activated Cdc2 kinase. Cell 74:463-474.

Hoffmann I, Clarke PR, Marcote MJ, Karsenti E, and Draetta G (1993) Phosphorylation and activation of human Cdc25-C by Cdc2-cyclin B and its involvement in the self-amplification of MPF at mitosis. EMBO (Eur Mol Biol Organ) J 12:53-63.

Jiang JD, Wang Y, Roboz J, Strauchen J, Holland JF, and Bekesi JG (1998) Inhibition of microtubule assembly in tumor cells by 3-bromoacetylamino benzoylurea, a new cancericidal compound. Cancer Res 58:2126-2133

Jordan A, Hadfield JA, Lawrence NJ, and McGown AT (1998) Tubulin as a target for anticancer drugs: agents which interact with the mitotic spindle. Med Res Rev 18:259-296.

Kavallaris M, Kuo DY, Burkhart CA, Regl DL, Norris MD, Haber M, and Horwitz SB (1997) Taxol-resistant epithelial ovarian tumors are associated with altered expression of specific beta-tubulin isotypes. J Clin Investig 100:1282-1293.

Kavallaris M, Tait AS, Walsh BJ, He L, Horwitz SB, Norris MD, and Haber M (2001) Multiple microtubule alterations are associated with Vinca alkaloid resistance in human leukemia cells. Cancer Res 61:5803-5809.

Korsmeyer SJ (1995) Regulators of cell death. Trends Genet 11:101-105.

Kumagai A and Dunphy WG (1991) The Cdc25 protein controls tyrosine dephosphorylation of the Cdc2 protein in a cell-free system. Cell 64:903-914.

Kuo Y-H and Wu C-H (1996) Synthesis of 5-(3-hydroxypropyl)-7-methoxy-2-(3'methoxy-4'-hydroxyphenyl)-3- benzo[b]furancarbaldehyde, a novel adenosine A1 receptor ligand from the root of Salvia miltiorrhizae. J Nat Prod (Lloydia) 59:625628.

Lin H-C, Ding H-Y, and Chang W-L (2001) Two new fatty diterpenoids from Salvia miltiorrhizae. J Nat Prod (Lloydia) 64:648-650.

Liu GT, Zhang TM, Wang BE, and Wang YW (1992) Protective action of seven 
natural phenolic compounds against peroxidative damage to biomembranes. Biochem Pharmacol 43:147-152.

Paull KD, Lin CM, Malspeis L, and Hamel E (1992) Identification of novel antimitotic agents acting at the tubulin level by computer-assisted evaluation of differential cytotoxicity data. Cancer Res 52:3892-3900.

Ramachandran C and Melnick SJ (1999) Multidrug resistance in human tumorsmolecular diagnosis and clinical significance. Mol Diagn 4:81-94.

Ranganathan S, Dexter DW, Benetatos CA, Chapman AE, Tew KD, and Hudes GR (1996) Increase of beta(III)- and beta(IVa)-tubulin isotopes in human prostate carcinoma cells as a result of estramustine resistance. Cancer Res 56:2584-2589.

Rowinsky EK, Cazenave LA, and Donehower RC (1990) Taxol: a novel investigational antimicrotubule agent. J Natl Cancer Inst 82:1247-1259.

Rowinsky EK and Donehower RC (1991) The clinical pharmacology and use of antimicrotubule agents in cancer chemotherapeutics. Pharmacol Ther 52:35-84

Russo AA, Jeffrey PD, and Pavletich NP (1996) Structural basis of cyclin-dependent kinase activation by phosphorylation. Nat Struct Biol 3:696-700.

Scammells PJ, Baker SP, and Beauglehole AR (1998) XH-14 analogues as adenosine antagonists. Bioorg Med Chem 6:1517-1524.

Scatena CD, Stewart ZA, Mays D, Tang LJ, Keefer CJ, Leach SD, and Pietenpol JA (1998) Mitotic phosphorylation of Bcl-2 during normal cell cycle progression and taxol-induced growth arrest. J Biol Chem 273:30777-30784.

Schiff PB and Horwitz SB (1980) Taxol stabilizes microtubules in mouse fibroblast cells. Proc Natl Acad Sci USA 77:1561-1565.

Strausfeld U, Labbe JC, Fesquet D, Cavadore JC, Picard A, Sadhu K, Russell P, and Doree M (1991) Dephosphorylation and activation of a P34cdc2/cyclin B complex in vitro by human CDC25 protein. Nature (Lond) 351:242-245.

Tahir SK, Han EK, Credo B, Jae HS, Pietenpol JA, Scatena CD, Wu-Wong JR, Frost D, Sham H, Rosenberg SH, et al. (2001) A-204197, a new tubulin-binding agent with antimitotic activity in tumor cell lines resistant to known microtubule inhibitors. Cancer Res 61:5480-5485.

Westendorf JM, Rao PN, and Gerace L (1994) Cloning of CDNAs for M-phase phosphoproteins recognized by the MPM2 monoclonal antibody and determination of the phosphorylated epitope. Proc Natl Acad Sci USA 91:714-718.

Wittmann T, Hyman A, and Desai A (2001) The spindle: a dynamic assembly of microtubules and motors. Nat Cell Biol 3:E28-E34.

Wu WL, Chang WL, and Chen CF (1991) Cytotoxic activities of tanshinones against human carcinoma cell lines. Am J Chin Med 19:207-216.

Yagi A, Fujimoto K, Tanonaka K, Hirai K, and Takeo S (1989) Possible active components of tan-shen (Salvia miltiorrhiza) for protection of the myocardium against ischemia-induced derangements. Planta Med 55:51-54.

Yang Z, Hon PM, Chui KY, Xu ZL, Chang HM, Lee CM, Cui YX, Wong HNC, Poon CD, and Fung BM (1991) Naturally occurring benzofuran: isolation, structure elucidation and total synthesis of 5-(3-hydroxypropyl)-7-methoxy-2-(3'-methoxy4'-hydroxyphenyl)-3-benzo[b]furancarbaldehyde, a novel adenosine $\mathrm{A}_{1}$ receptor ligand isolated from Salvia miltiorrhiza bunge (Danshen). Tetrahedron Lett 32: 2061-2064.

Yang Z, Liu HB, Lee CM, Chang HM, and Wong HNC (1992) Compounds From Danshen. Part 7. Regioselective introduction of carbon-3 substituents to 5-alkyl7-methoxy-2-phenylbenzo[b]furans: synthesis of a novel adenosine A1 receptor ligand and its derivatives. J Org Chem 57:7248-7257.

Address correspondence to: Dr. Jang-Yang Chang, Cancer Cooperative ward in National Taiwan University Hospital, Division of Cancer Research National Health Research Institutes, 7 Chung-Shang South Road, Taipei, Taiwan. E-mail: jychang@nhri.org.tw 